\title{
Screening of Chilean fish-killing microalgae using a gill cell-based assay
}

\author{
Jorge I. Mardones ${ }^{1}$ \\ ${ }^{1}$ Centro de Estudios de Algas Nocivas (CREAN), Instituto de Fomento Pesquero (IFOP) \\ Puerto Montt, Chile \\ Corresponding author: Jorge I. Mardones (jorge.mardones@ifop.cl)
}

\begin{abstract}
Fish-killing algal species are responsible for important global economic losses to the finfish industry. Chile is the world's second-largest salmon exporter, and fish-killing algal blooms have widely impacted its production in the last decades. The lack of standardized analytical methods to quantify and characterize the so-called "ichthyotoxins" has hindered our understanding of the underlying ichthyotoxic modes of action. The novel application of a highly sensitive and reproducible fish RTgill-W1 cell line-based assay has allowed significant progress in the field. In this study, the ichthyotoxic potency of the main microalgae species, which has been reported in fish-killing events in the historical Chilean monitoring programs, was assessed. The dinoflagellate Karenia selliformis was the most ichthyotoxic species against the RTgill-W1 (cell viability down to $8 \%$ ), representing the major threat for the local salmon industry. In comparison, the raphidophyte Heterosigma akashiwo and the dinoflagellate Prorocentrum micans were the least toxic (gill cell viability down to 81 and $89 \%$, respectively). Importantly, ichthyotoxic flagellates were more toxic to fish gill cells upon rupture. These results have important implications for the mitigation and management of algal blooms by the salmon industry.
\end{abstract}

Keywords: harmful algal blooms; salmon farming; ichthyotoxic; gill damage; RTgill-W1; fish-kills; Chilean fjords

The 2016 "Godzilla Red Tide" event caused the most catastrophic episode in the history of the Chilean aquaculture due to the convergence of two potent toxic microalgae, the dictyochophyte Pseudochattonella verruculosa and the dinoflagellate Alexandrium catenella. This massive event produced the largest fish farm mortality ever recorded worldwide (export loss of USD 800 million), which when combined with PSP shellfish toxicity ( $\sim 15 \%$ reduction in harvest compared to 2015), resulted in major social unrest and rioting in the south of Chile (Trainer et al., 2020). Historical fishkilling harmful algal bloom (HAB) events have, however, been reported along the southern Chilean fjords since the development of the salmon farming industry in 1982 (Table 1). Fish mortalities have been often associated with the rapid growth of harmful microalgal species, but this noxious effect can also be associated with harmless species because high biomass of any phytoplankton can generate oxygen depletion in the water column at the end of bloom due to bacterial degradation, as well as gas-bubble trauma due to extreme oxygen saturation from algal photosynthesis (Lutz, 1995). However, some microalgal species can kill fish at low cell concentrations via a high impact on the gill tissues. Two main mechanisms for fish gill damage by microalgae have been proposed: 1) damage due to the presence of penetrating or cutting microstructures, and 2) due to the production of the so-called "ichthyotoxins" (Hallegraeff et al., 2017). Research on the latter has been an enormous scientific challenge because the production of these metabolites often differs from the well-studied paralytic, diarrheic, amnesic and neurotoxic phycotoxins.

The novel application of a standardized and highly sensitive, repeatable and reproducible rainbow trout Oncorhynchus mykiss RTgill-W1 cell line assay (Fischer et al., 2019) has become a popular screening tool for assessing toxicity of algal blooms in several im- 
Table 1. Summary of the main historical fish-killing algal blooms recorded in the south of Chile. The most damaging events are ranked according to their economic impact (Harmful effect: X -unknown, I -ichthyotoxic, M -mechanical gill damage).

\begin{tabular}{|c|c|c|c|c|c|c|c|}
\hline Ranking & Species & Date & Location & Region & Impact & $\begin{array}{c}\text { Harmful } \\
\text { effect }\end{array}$ & Reference \\
\hline & Prorocentrum micans & 1983 & Seno Reloncaví & Los Lagos & Wild fish mortality & $\mathrm{X}$ & $\begin{array}{l}\text { Lembeye \& } \\
\text { Campodonico (1984) }\end{array}$ \\
\hline \multirow[t]{13}{*}{6} & Heterosigma akshiwo & September, 1988 & $\begin{array}{l}\text { Seno Reloncaví, } \\
\text { Hornopirén }\end{array}$ & Los Lagos & $\begin{array}{l}\text { Salmon Mortality } \\
(>5,000 \mathrm{t})\end{array}$ & I & $\begin{array}{l}\text { Clément \& Lembeye } \\
\text { (1993) }\end{array}$ \\
\hline & Leptocilyndrus inimum & November, 1989 & Chiloé & Los Lagos & Salmon mortality & M & Clément (1994) \\
\hline & Chaetoceros convolutus & July, 1991 & Hornopirén & Los Lagos & Salmon mortality & M & Fuica et al. (2007) \\
\hline & Leptocilyndrus minimum & $\begin{array}{l}\text { October and } \\
\text { December, } 1993\end{array}$ & $\begin{array}{l}\text { Chiloé Island and } \\
\text { Calbuco }\end{array}$ & Los Lagos & Salmon mortality & M & Clément (1994) \\
\hline & Leptocilyndrus minimum & $\begin{array}{l}\text { January and } \\
\text { December, } 1994\end{array}$ & Chiloé Island & Los Lagos & Salmon mortality & M & Fuica et al. (2007) \\
\hline & Chaetoceros convolutus & $\begin{array}{l}\text { January-April, } \\
1995\end{array}$ & $\begin{array}{l}\text { Seno Reloncaví- } \\
\text { Chiloé Island }\end{array}$ & Los Lagos & Salmon mortality & M & Fuica et al. (2007) \\
\hline & Dictyocha speculum & March, 1995 & Chiloé Island & Los Lagos & Salmon mortality & M & Fuica et al. (2007) \\
\hline & Chaetoceros convolutus & May, 1997 & Seno Reloncaví & Los Lagos & Salmon mortality & M & Fuica et al. (2007) \\
\hline & Leptocilyndrus minimum & $\begin{array}{l}\text { July and } \\
\text { December, } 1998\end{array}$ & $\begin{array}{l}\text { Seno Reloncaví- } \\
\text { Chiloé Island }\end{array}$ & Los Lagos & Salmon mortality & M & Fuica et al. (2007) \\
\hline & Karenia selliformis & March, 1999 & Chiloé Island & Los Lagos & Salmon mortality & I & $\begin{array}{l}\text { Clément et al. } \\
\text { (2001); Guillou et al. } \\
(2002)\end{array}$ \\
\hline & Chaetoceros convolutus & May, 1999 & Seno Reloncaví & Los Lagos & Salmon mortality & M & Fuica et al. (2007) \\
\hline & Heterosigma akashiwo & March, 2000 & Seno Reloncaví & Los Lagos & Salmon mortality & I & Fuica et al. (2007) \\
\hline & Heterosigma akashiwo & March, 2002 & Reñihue & Los Lagos & Salmon mortality & I & $\begin{array}{l}\text { Mardones et al. } \\
\text { (2012) }\end{array}$ \\
\hline \multirow[t]{3}{*}{5} & Alexandrium catenella & $\begin{array}{l}\text { October-April, } \\
2002\end{array}$ & $\begin{array}{l}\text { Chiloé Island- } \\
\text { Moraleda Channel }\end{array}$ & Los Lagos-Aysén & $\begin{array}{l}\text { Three human } \\
\text { fatalities/50 intoxicated/ } \\
1,800 \mathrm{t} \text { salmon mortality }\end{array}$ & I & Molinet et al. (2003) \\
\hline & Leptocilyndrus danicus & February, 2004 & Lemuy Channel & Los Lagos & Salmon mortality & M & Fuica et al. (2007) \\
\hline & Pseudochattonella spp. & 2004 & $\begin{array}{l}\text { Seno Reloncaví- } \\
\text { Chiloé Island }\end{array}$ & Los Lagos & Salmon mortality & I & $\begin{array}{l}\text { Mardones et al. } \\
(2012)\end{array}$ \\
\hline \multirow[t]{2}{*}{4} & Alexandrium catenella & 2006 & Chiloé Island-Aysén & Los Lagos-Aysén & $\begin{array}{l}\text { One human } \\
\text { fatality/seven } \\
\text { intoxicated/salmon } \\
\text { mortality }\end{array}$ & I & Fuentes et al. (2008) \\
\hline & Pseudochattonella spp. & 2009 & $\begin{array}{l}\text { Seno Reloncaví- } \\
\text { Chiloé Island }\end{array}$ & Los Lagos & Salmon mortality & I & $\begin{array}{l}\text { Mardones et al. } \\
\text { (2012) }\end{array}$ \\
\hline \multirow[t]{4}{*}{3} & Alexandrium catenella & $\begin{array}{l}\text { February-April, } \\
2009\end{array}$ & 43 to $47^{\circ} \mathrm{S}$ & Los Lagos-Aysén & $\begin{array}{l}\text { Two human fatalities/20 } \\
\text { intoxicated/salmon } \\
\text { mortality (>USD 10M) }\end{array}$ & I & $\begin{array}{l}\text { Mardones et al. } \\
(2010,2015)\end{array}$ \\
\hline & Chaetoceros criophylus & June, 2014 & Seno Reloncaví & Los Lagos & Salmon mortality & M & INTESAL* \\
\hline & $\begin{array}{l}\text { Thalassiosira } \\
\text { pseudonana }\end{array}$ & December, 2014 & Aysén fjord & Aysén & Salmon mortality & $\mathrm{x}$ & INTESAL* \\
\hline & $\begin{array}{l}\text { Thalassiosira } \\
\text { pseudonana }\end{array}$ & March, 2016 & Seno Reloncaví & Los Lagos & Salmon mortality & $\mathrm{x}$ & INTESAL* \\
\hline 2 & $\begin{array}{l}\text { Pseudochattonella } \\
\text { verruculosa }\end{array}$ & $\begin{array}{l}\text { January-March, } \\
2016\end{array}$ & $\begin{array}{l}\text { Seno Reloncaví- } \\
\text { Chiloé Island }\end{array}$ & Los Lagos & $\begin{array}{l}\text { Salmon mortality } \\
(>\text { US } \$ 800 \mathrm{M} ; 40,000 \mathrm{t})\end{array}$ & I & $\begin{array}{l}\text { Clément et al. } \\
\text { (2016); Mardones et } \\
\text { al. (2019) }\end{array}$ \\
\hline \multirow[t]{4}{*}{1} & Alexandrium catenella & March-May, 2016 & $\begin{array}{l}\text { offshore bloom; } 39 \\
\text { to } 45^{\circ} \mathrm{S}\end{array}$ & $\begin{array}{l}\text { Aysén, Los } \\
\text { Lagos, Los Ríos }\end{array}$ & $\begin{array}{l}\text { Massive mortality of } \\
\text { marine species }\end{array}$ & I & IFOP (2016) \\
\hline & Karenia spp. & $\begin{array}{l}\text { January-February, } \\
2017\end{array}$ & $46^{\circ} \mathrm{S}$ & $\begin{array}{l}\text { Aysén- } \\
\text { Magallanes }\end{array}$ & Salmon mortality (121 t) & I & $\begin{array}{l}\text { SERNAPESCA } \\
(2017)^{*}\end{array}$ \\
\hline & Karenia selliformis & February, 2018 & Quellón, Chiloé & Los Lagos & $\begin{array}{l}\text { Salmon mortality }(1,600 \\
\text { t) }\end{array}$ & I & $\begin{array}{l}\text { SERNAPESCA } \\
(2018)^{*}\end{array}$ \\
\hline & $\begin{array}{l}\text { Pseudochattonella } \\
\text { verruculosa; Vicicitus } \\
\text { globosus }\end{array}$ & March, 2019 & Pilpilehue, Chiloé & Los Lagos & Salmon mortality $(150 \mathrm{t})$ & I & $\begin{array}{l}\text { SERNAPESCA } \\
(2019)^{*}\end{array}$ \\
\hline
\end{tabular}

*Data from the Instituto Tecnológico del Salmon (INTESAL, Chile) were obtained from monthly reports kindly provided by INTESAL's data managers and data from the Servicio Nacional de Pesca (SERNAPESCA, Chile) were obtained from annual salmon farming health reports (www.sernapesca.cl).

pacted coasts (Tanneberger et al., 2013; DorantesAranda et al., 2015; Natsch et al., 2018). Through this cell line assay, ichthyotoxic compounds produced by Chilean strains of $A$. catenella and $P$. verruculosa have been initially explored (Mardones et al., 2015, 2018, 2019). Synergism between the long-chain $(\geq \mathrm{C} 20)$ polyunsaturated fatty acids (PUFA) docosahexaenoic

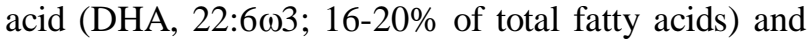


reactive oxygen species (ROS -as superoxide anion) has been suggested as a primary ichthyotoxic mechanism in A. catenella, but cannot be explained by paralytic shellfish toxins (Mardones et al., 2015, 2018). Furthermore, the role of mucocysts has been pointed for a more in-depth research insight, which could provide a greater understanding as to the harmful mode of action of $P$. verruculosa (Mardones et al., 2019).

Ichthyotoxic microalgae is a major concern for the Chilean Government, and thus highly expensive monitoring programs are conducted along the southern Patagonian coast. Despite such monitoring efforts, many of the fish-killing microalgae species that occur in the Chilean fjords are practically unstudied concerning their potential toxicities. As a result, it is frequent that Chilean monitoring programs alert fish farmers about the presence of a "putative" ichthyotoxic microalgae species only based on their ichthyotoxic characteristics reported in other coastal areas.

This study aims to assess the ichthyotoxic potency of the main microalgae species that has been reported in fish-killing events in the historical Chilean monitoring programs, in order to rank their potential impact on the local aquaculture.

Nine potentially ichthyotoxic microalgae strains and one non-toxic species (Teleaulax sp. as a control treatment) were obtained from the Harmful Algal Collection of the Centro de Estudios de Algas Nocivas in Chile (CREAN/IFOP) (Table 2). Algae were grown in $\mathrm{F} / 2$ medium using seawater at 30 of salinity and kept at $17^{\circ} \mathrm{C}$ under $16: 8 \mathrm{~h}$ light:dark cycle at $100 \mu \mathrm{mol}$ photons $\mathrm{m}^{-2} \mathrm{~s}^{-1}$ of light intensity (cool white fluorescent lamp). The gill cell line RTgill-W1, originally from rainbow trout (Bols et al., 1994), was obtained from the American Type Culture Collection (CRL-2523, ATCC). Cells were cultured at $17^{\circ} \mathrm{C}$ in the dark in Leibovitz's L-15 medium (L1518 Sigma), supplemented with $10 \%(\mathrm{v} / \mathrm{v})$ fetal bovine serum (FBS, 12003C, Sigma), and an antibiotic-antimycotic solution (A5955, Sigma) containing amphotericin B $\left(25 \mathrm{mg} \mathrm{mL}^{-1}\right)$, streptomycin $\left(10 \mathrm{mg} \mathrm{mL}^{-1}\right)$ and penicillin $(10,000$ units $\left.\mathrm{mL}^{-1}\right)$ in $25 \mathrm{~cm}^{2}$ culture-treated flasks (3100-025, Iwaki). $0.25 \%$ trypsin- $0.02 \%$ EDTA in Hank's balanced salt solution (59428C, Sigma) was used to detach cells that grew as an adherent monolayer at the bottom of the flask. Subcultures were normally established twice per week at a ratio of 1:2 with L-15 medium renewal.

The cytotoxicity assay with the 10 microalgae strains was carried out using conventional multi-well microplates, according to Dorantes-Aranda et al. (2011). Cultures with confluent gill cells were trypsinized (59428C, Sigma) for detachment, counted using a hemocytometer and adjusted to a concentration of $2 \times 10^{5}$ cells $\mathrm{mL}^{-1}$ in L-15 medium. Subsequently, gill cells were seeded in quadruplicate in 96-well flatbottom microplates (3860-096, Iwaki, Japan), using a volume of $100 \mu \mathrm{L}$ per well. After $48 \mathrm{~h}$ at $17^{\circ} \mathrm{C}$ in the dark for gill cell attachment, L-15 medium was discarded, the cells rinsed with PBS and exposed to 100 $\mu \mathrm{L}$ of lysed cells and supernatant medium from the 10 strain cultures at 30 of salinity at $17^{\circ} \mathrm{C}$ in the dark. Supernatant and lysed cell treatments were prepared from all cultures in the exponential growth phase at 2,000 cells $\mathrm{mL}^{-1}$. The lysed cell suspension was prepared by sonication of diluted samples for $10 \mathrm{~min}$ at an amplitude of $10 \mu \mathrm{m}$ peak to peak at $17^{\circ} \mathrm{C}$ and filtered using a syringe with a nylon filter $(0.22 \mu \mathrm{m})$. After two hours exposure, the viability of the gill cells was determined using L-15/ex medium (Schirmer et al., 1997), a modified version of the L-15 medium, containing $5 \%$ of the indicator dye alamarBlue (DAL1025, Invitrogen) (Pagé et al., 1993). The medium containing the indicator dye was added to all cell-seeded wells and incubated for one hour in the dark (Dayeh et al., 2005). Using a microplate reader (FLUOstar OMEGA, BMG Labtech), the fluorescence signal of alamarBlue was detected using excitation and emission filters of 540 and $570 \mathrm{~nm}$, respectively. The viability of the gill cells was expressed as a response percentage of the treatments relative to the controls (\% of control). Analysis of variance (ANOVA) from simple linear regression models on gill cell viability against intra- and extracellular compounds was performed, to explore the ichthyotoxic of the 10 microalgae strains. Normality and homogeneity of variances were assessed by the Kolmogorov-Smirnov method and Levene's test. A post-hoc analysis using a Tukey HSD test was performed to determine differences among treatments. The null hypothesis (no difference in responses) was rejected in all statistical analyses if the respective $P$-value was $<0.05$. These analyses were performed using the $\mathrm{R}$ software 3.0.1 (Ihaka \& Gentleman, 1996). Algal biovolume was calculated according to Hillebrand et al. (1999).

Historical monitoring data in Chile shows that after the startup of the salmon industry in 1982, the first harmful algal blooms (HABs) producing fish-kills were related to the occurrence of flagellates of the class Dinophyceae and Raphydophyceae. During the 90's, salmon mortalities were mainly linked to harmful diatoms of the genus Leptocylindrus and Chaetoceros, whereas since 2000, there has been an increase in the intensity, duration and geographic coverage of ichthyotoxic flagellates (see the type of harmful effect in Table 1). This study tested the ichthyotoxic potency of the most recurrent phytoflagellates producing fishkilling events in the last 36 years in southern Chile (Fig. 1, Table 2). After two hours exposure of microalgae 


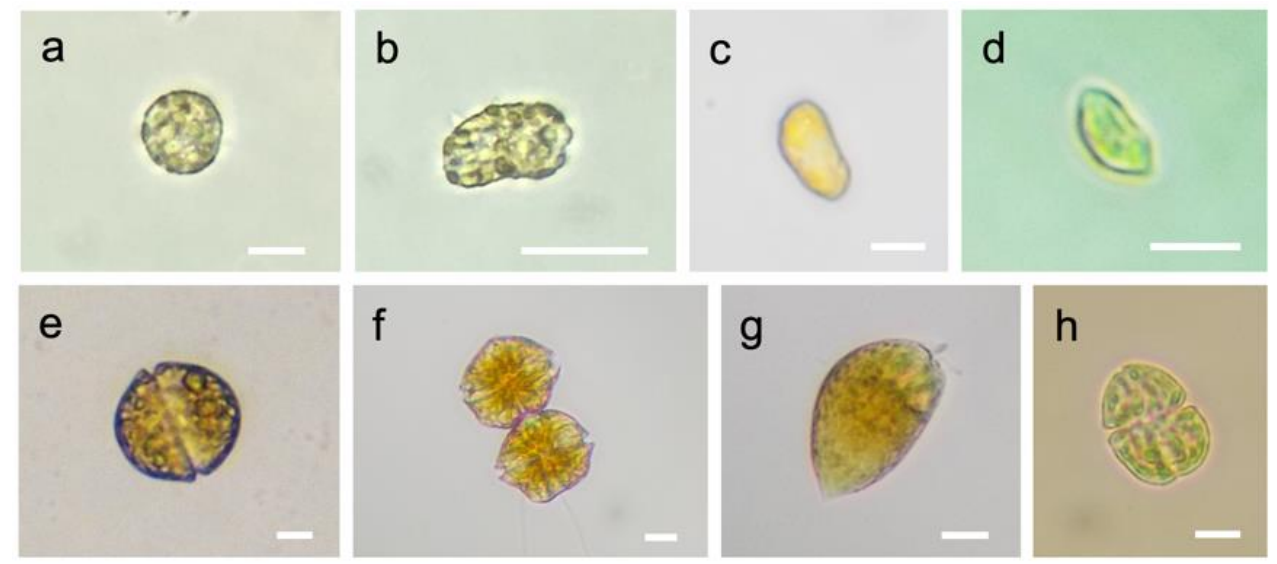

Figure 1. Microalgae species used in the study. a) Vicicitus globosus, b) Pseudochattonella verruculosa, c) Heterosigma akashiwo, d) Teleaulax sp., e) Alexandrium ostenfeldii, f) Alexandrium catenella, g) Prorocentrum micans, and h) Karenia selliformis. Scale bar: $10 \mu \mathrm{m}$.

Table 2. Species of marine microalgae used for exposure experiments to test their toxicity on fish gill cells RTgill-W1. The nontoxic species Teleaulax sp. was used as a negative control. *(Original code: ARC498).

\begin{tabular}{llcll}
\hline Class & Species & Strain code & Origen & Isolator (Year) \\
\hline Cryptophyceae & Teleaulax sp. & TL_01 & Reloncaví Fjord/Los Lagos & J.I. Mardones (2019) \\
Dictyochophyceae & Pseudochattonella verruculosa & PV_01* & Huar Island/Los Lagos & A. Martin (2016) \\
& Pseudochattonella verruculosa & PV_06 & Pilpilehue/Los Lagos & J.I. Mardones (2019) \\
& Vicicitus globosus & VG_01 & Hualaihué/Los Lagos & J.I. Mardones (2019) \\
Dinophyceae & Alexandrium catenella & AC_01 & Asasao/Aysén & B. Olivares (2019) \\
& Alexandrium ostenfeldii & AO_01 & Calbuco/Los Lagos & J.I. Mardones (2018) \\
& Karenia selliformis & KS_01 & Guaitecas/Aysén & J.I. Mardones (2018) \\
& Karenia selliformis & KS_02 & Guaitecas/Aysén & J.I. Mardones (2018) \\
& Prorocentrum micans & PM_01 & Reloncaví Sound/Los Lagos & J.I. Mardones (2018) \\
Raphidophyceae & Heterosigma akashiwo & HA_01 & Hornopirén/Los Lagos & J.I. Mardones (2019) \\
\hline
\end{tabular}

Strains were obtained from the Harmful Algal Collection of the Centro de Estudios de Algas Nocivas in Chile (CREAN/IFOP).

cultures against fish gill cells, all algae cultures except the control (Teleaulax sp.) and one Karenia strain (KS_01), showed significant differences in the gill cell viability response between the supernatant and lysed cell algae treatments (Figs. 2a-b; ANOVA, $P<0.05$ ), and no correlation with algal biovolume (Fig. 2 c; $\mathrm{R}^{2}<$ 0.001 ). This result agrees with several studies that have shown that ruptured microalgae cells exhibit consistently higher toxicity than supernatant against RTgill-W1 cells (Dorantes-Aranda et al., 2011, 2015; Mooney et al., 2011; Mardones et al., 2015). While specific lytic compounds produced by some phytoflagellates are released into the surrounding aquatic environment, the most active portion remains cell-bound. Based on these findings, mitigation approaches that are currently used in salmon farms during bloom events, where the main target is to destroy the harmful algae cells (by rupturing), are likely to make effects worse.
As observed in the lysed-cells treatment (the most toxic fraction), the most cytotoxic species at 2,000 cells $\mathrm{mL}^{-1}$-in decreasing order- were Karenia selliformis, $A$. catenella, Vicicitus globosus, Alexandrium ostenfeldii, P. verruculosa, Heterosigma akashiwo, and Prorocentrum micans (Fig. 2b). Except for K. selliformis and A. catenella, the cytotoxic potency observed in all surveyed species is low, considering that 2,000 cells $\mathrm{mL}^{-1}$ could be accepted as an intense HAB event in natural oceanic conditions. Assuming that ichthyotoxins are equivalent to allelopathic compounds, our results could be a consequence of in vitro monoclonal cultures, where the microalgae do not require the release of toxic compounds under no competence nor predation pressure. This outcome might partially explain the observed mismatch in ichthyotoxic potency between natural algae blooms (higher toxicity) and laboratory studies on target species (lower toxicity). 

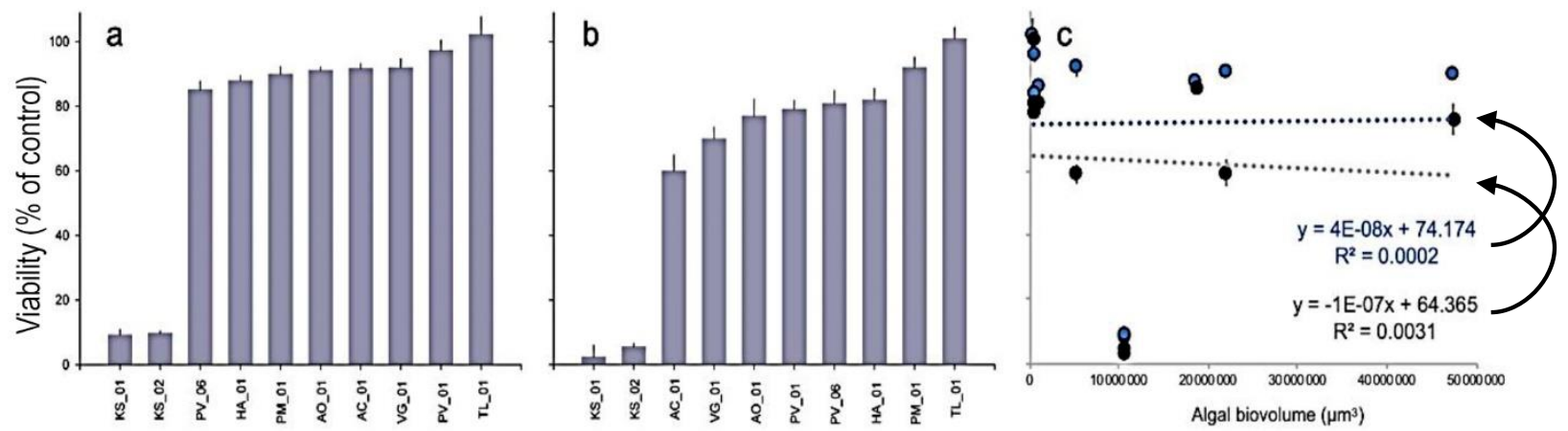

Figure 2. Loss of viability of RTgill-W1 cells after $2 \mathrm{~h}$ exposure to a range of algal cultures, arranged from most ichthyotoxic (left) to harmless (right). a) supernatant, b) lysed cells, and c) effect of supernatant (blue circles) and lysed cell (black circles) treatments on gill cell viability estimated from total algal biovolume. The trend line and equation of linear adjustment are presented for all data. The nontoxic species Teleaulax sp. was used as a negative control. VG_01: Vicicitus globosus, PV_01 and PV_06: Pseudochattonella verruculosa, HA_01: Heterosigma akashiwo, TL_01: Teleaulax sp., AO_01: Alexandrium ostenfeldii, AC_01: Alexandrium catenella, PM_01: Prorocentrum micans, KS_01 and KS_02: Karenia selliformis.

Coupling historical fish-killing events (Table 1) and results in this study regarding the ichthyotoxic potency of algae species, two main considerations should be taken into account by the Chilean salmon industry. First, Karenia selliformis has been observed to bloom in offshore areas (2-10 NM), barely affecting inshore salmon farming activities $\left(<2\right.$ cells $\left.\mathrm{mL}^{-1}\right)$. Exceptional outbreaks of this toxic dinoflagellate, in inner channels, might, however, be even more damaging than the Pseudochattonella bloom recorded in 2016 (Mardones et al., 2019); thus, early warning systems should be activated when the presence of this dinoflagellate species. Second, according to the present historical analysis, there is an apparent increment in the occurrence of phytoflagellates and their ichthyotoxic potency during the last decade in southern Chile (see the ranking in Table 1). This fact might be the result of enhanced monitoring efforts (especially from the salmon farming industry) and improved expertise in taxonomic identification of cryptic toxic flagellates species, but also due to the observed resilience of some toxic flagellate to projected climate variability in the eastern Pacific coast (Mardones et al., 2016). Expected climate change or exceptional warmer environmental conditions might increase the occurrence of ichthyotoxic microalgae, as reported by Trainer et al. (2020).

In conclusion, this study has shown that the application of an in vitro fish gill assay is an effective method to carry out sensitive screening tests for the toxicity of marine microalgae. An important output to consider by salmon farmers is that ichthyotoxic flagellates are more toxic to fish gill cells upon rupture and that Karenia spp. are more toxic than previously thought. These results have important implications for the way the salmon industry should manage and mitigate algal bloom impacts.

\section{ACKNOWLEDGMENTS}

The author thanks all the members of the CREAN laboratory for their constructive comments on the study. Funding was provided by the Instituto de Fomento Pesquero (IFOP) (Grants MR656-114, MR656-123, and CORFO 480-018).

\section{REFERENCES}

Bols, N., Barlian, A., Chirino-Trejo, M., Caldwell, S., Goegan, P. \& Lee, L.E.J. 1994. Development of a cell line from primary cultures of rainbow trout, Oncorhynchus mikiss (Walbaum), gill. Journal of Fish Diseases, 17: 601-611.

Clément, A. 1994. Harmful blooms of Leptocylindrus minimus in southern Chile. Harmful Algae News, 8: 1.

Clément, A. \& Lembeye, G. 1993. Phytoplankton monitoring programme in the fish farm region of the south of Chile. In: Smayda, T.J. \& Shimizu, Y. (Eds.). Toxic phytoplankton blooms in the sea. Elsevier, Amsterdam, pp. 223-228.

Clément, A., Seguel, M., Arzul, G., Guzmán, L. \& Alarcón, C. 2001. Widespread outbreak of hemolytic, ichthyotoxic Gymnodinium sp. in southern Chile. In: Hallegraeff, G.M., Blackburn, S.I. \& Lewis, R.J. (Eds.). Harmful algal blooms. Intergovernmental Oceanographic Commission of UNESCO, Paris. 
Clément, A., Lincoquero, L., Saldivia, M., Brito, C.G., Muñoz, F., Fernández, C., Pérez, F., Maluje, C., Correa, N., Moncada, V. \& Contreras, G. 2016. Exceptional summer conditions and HABs of Pseudochattonella in southern Chile create record impacts on salmon farms. Harmful Algal News, 53: 1-3.

Dayeh, V.R., Schirmer, K., Lee, L.E.J. \& Bols, N.C. 2005. Rainbow trout gill cell line microplate cytotoxicity test. In: Blaise, C. \& Férard, J.F. (Eds.). Small-scale freshwater toxicity investigations. Springer, Amsterdam, pp. 473-503.

Dorantes-Aranda, J.J., Seger, A., Mardones, J.I., Nichols, P.D. \& Hallegraeff, G.M. 2015. Progress in understanding algal bloom-mediated fish kills: the role of superoxide radicals, phycotoxins, and fatty acids. Plos One: 10:e0133549. doi: 10.1371/journal.pone. 0133549

Dorantes-Aranda, J.J., Waite, T.D., Godrant, A., Rose, A., Tovar, C.D., Woods, G.M. \& Hallegraeff, G.M. 2011. Novel application of a fish gill cell line assay to assess ichthyotoxicity of harmful marine microalgae. Harmful Algae, 10: 366-373.

Fischer, M., Belanger, S.E., Berckmans, P., Bernhard, M.J., Bláha, L., Coman-Schmid, D.E., et al. 2019. Repeatability and reproducibility of the RTgill-W1 cell line assay for predicting fish acute toxicity. Toxicological Sciences, 169(2): 353-364.

Fuentes-Grünewald, C., Aguilera, A. \& Clément, A. 2008. Summer Alexandrium catenella bloom and the impact on fish farming, in the XI Aysén region, Chile. In: Moestrup, O., Doucette, G., Enevoldsen, H., Godhe, A., Hallegraeff, G., Luckas, B., et al. (Eds.). Proceedings of $12^{\text {th }}$ International Conference on Harmful Algae. International Society for the Study of Harmful Algae and Intergovernmental Oceanographic Commission of UNESCO, Paris.

Fuica, N., Rojas, X., Clément, A., Bittner, V., Silva, M. \& Uribe, C. 2007. Ocurrencia e impacto de las FANs en la salmonicultura en el sur de Chile: análisis del programa de monitoreo de INTESAL de Salmón Chile. Salmociencia, 2: 61-71.

Guillou, L., Nezán, E., Cueff, V., Erard-Le Denn, E., Cambon-Bonavita, M., Gentien, P. \& Barbier, G. 2002. Genetic diversity and molecular detection of three toxic dinoflagellate genera (Alexandrium, Dinophysis, and Karenia) from French coasts. Protist, 153: 223-238.

Hallegraeff, G.M., Dorantes-Aranda, J.J., Mardones, J.I. \& Seger, A. 2017. Review of progress in our understanding of fish-killing microalgae: implications for management and mitigation. In: Proença, L.A.O. \& Hallegraeff, G.M. (Eds.). Marine and fresh-water harmful algae. Proceedings of the $17^{\text {th }}$ International
Conference on Harmful Algae. International Society for the Study of Harmful Algae and Intergovernmental Oceanographic Commission of UNESCO, Paris.

Hillebrand, H., Dürselen, C.D., Pollingher, U. \& Zohary, T. 1999. Biovolume calculation for pelagic and benthic microalgae. Journal of Phycology, 35: 403424.

Ihaka, R. \& Gentleman, R. 1996. A language for data analysis and graphics. Journal of Computational and Graphical Statistics, 5: 299-314.

Lembeye, G. \& Campodonico, I. 1984. First recorded bloom of the dinoflagellate Prorocentrum micans Ehr. in south-central Chile. Botanica Marina, 27(10): 491493.

Lutz, D.S. 1995. Gas supersaturation and gas bubble trauma in fish downstream from a midwestern reservoir. Transactions of the American Fisheries Society, 124(3): 423-436.

Mardones, J., Clément, A. \& Rojas, X. 2012. Monitoring potentially ichthyotoxic phytoflagellates in southern fjords of Chile. Harmful Algae News, 45: 6-7.

Mardones, J.I., Müller, M.N. \& Hallegraeff, G.M. 2016. Toxic dinoflagellate blooms of Alexandrium catenella in Chilean fjords: a resilient winner from climate change. ICES Journal of Marine Science, 74(4): 988995. doi:10.1093/icesjms/fsw164

Mardones, J., Clément, A., Rojas, X. \& Aparicio, C. 2010. Alexandrium catenella during 2009 in Chilean waters, and recent the expansion to coastal ocean. Harmful Algae News, 41: 8-9.

Mardones, J.I., Dorantes-Aranda, J.J., Nichols, P.D. \& Hallegraeff, G.M. 2015. Fish gill damage by the dinoflagellate Alexandrium catenella from Chilean fjords: synergistic action of ROS and PUFA. Harmful Algae, 49: 40-49.

Mardones, J.I., Fuenzalida, G., Zenteno, K., Alves-deSouza, C., Astuya, A. \& Dorantes-Aranda, J.J. 2019. Salinity-growth response and ichthyotoxic potency of the Chilean Pseudochattonella verruculosa. Frontiers in Marine Science, 6(24): 12 pp. doi: 10.3389/fmars. 2019. 00024

Mardones, J.I., Shabala, L., Shabala, S., Dorantes-Aranda, J.J., Seger, A. \& Hallegraeff, G.M. 2018. Fish gill damage by harmful microalgae newly explored by microelectrode ion flux estimation techniques. Harmful Algae, 80: 55-63.

Molinet, C., Lafón, A., Lembeye, G. \& Moreno, C. 2003. Patrones de distribución espacial y temporal de floraciones de Alexandrium catenella (Whedon \& Kofoid) Balech 1985, en aguas interiores de la Patagonia noroccidental de Chile. Revista Chilena de Historia Natural, 76: 681-698.

Mooney, B.D., Dorantes-Aranda, J.J., Place, A.R. \& Hallegraeff, G.M. 2011. Ichthyotoxicity of gymno- 
dinioid dinoflagellates: PUFA and superoxide effects in sheepshead minnow larvae and rainbow trout gill cells. Marine Ecology Progress Series, 426: 213-224.

Natsch, A., Laue, H., Haupt, T., Von Niederhäusern, V. \& Sanders, G. 2018. Accurate prediction of acute fish toxicity of fragrance chemicals with the RTgill-W1 cell assay. Environmental Toxicology and Chemistry, 37(3): 931- 941.

Pagé, B., Pagé, M. \& Noël, C. 1993. A new fluorometric assay for cytotoxicity measurements in vitro. International Journal of Oncology, 3: 473-476.

Received: 11 July 2019; Accepted: 6 October 2019
Schirmer, K., Chan, A.G.J., Greenberg, B.M., Dixon, D.G. \& Bols, N.C. 1997. Methodology for demonstrating and measuring the photocytotoxicity of fluoranthene to fish cells in culture. Toxicology in Vitro, 11: 107-119.

Tanneberger, K., Knobel, M., Busser, F.J., Sinnige, T.L., Hermens, J.L. \& Schirmer, K. 2013. Predicting fish acute toxicity using a fish gill cell line-based toxicity assay. Environmental Science \& Technology, 47(2): 1110-1119.

Trainer, V.L., Moore, S.K., Hallegraeff, G.M., Kudela, R.M., Clément, A., Mardones, J.I. \& Cochlan, W.P. 2020. Pelagic harmful algal blooms and climate change: lessons from nature's experiments with extremes. Harmful Algae, 91: 101591. doi: 10.1016/ j.hal.2019. 03.009 